\title{
Bibliographical Notes on Charles Sealsfield
}

\section{Author(s): Otto Heller}

Source: The Modern Language Review, Vol. 3, No. 4 (Jul., 1908), pp. 360-365

Published by: Modern Humanities Research Association

Stable URL: http://www.jstor.org/stable/3713205

Accessed: 21-06-2016 18:50 UTC

Your use of the JSTOR archive indicates your acceptance of the Terms \& Conditions of Use, available at

http://about.jstor.org/terms

JSTOR is a not-for-profit service that helps scholars, researchers, and students discover, use, and build upon a wide range of content in a trusted digital archive. We use information technology and tools to increase productivity and facilitate new forms of scholarship. For more information about JSTOR, please contact support@jstor.org.

Modern Humanities Research Association is collaborating with JSTOR to digitize, preserve and extend access to The Modern Language Review 


\section{BIBLIOGRAPHICAL NOTES ON CHARLES SEALSFIELD.}

DURING a recent investigation of certain aspects of Sealsfield's life I have been forced to the conclusion that, if a wholly reliable biography of that author is to be written, nearly all the accepted data will have to be subjected to a thorough re-examination. The following notes are a contribution to the bibliography of certain of Sealsfield's writings.

\section{The United States.}

It is generally agreed that the first published work of Sealsfield, Die Vereinigten Staaten von Nordamerika, etc., Stuttgart, Cotta, 1827, was worked over by the author into two English books, the one entitled The Americans as they are, etc., London, Hurst, Chance and Co., 1828; the other, The United States of North America, as they are in their political, religious and social bearings, London, John Murray, 1828. The first-named, according to A. B. Faust, Charles Sealsfield, der Dichter beider Hemisphären, Weimar, 1896, p. 59, consists of those portions of Vol. II of the German original which were rejected by John Murray; so that by far the greatest part of Vol. II must have been cut out by Murray, since The Americans runs to 218 pages. The Americans is one of the least accessible of Sealsfield's works. As for The United States, no copy of it is known to exist in any library, not even in the British Museum or the Bodleian. Its entire disappearance is in a way explained by the report of Mr C. G. Lawrence, who, upon my request to Mr Murray of Albemarle Street, was kindly commissioned by him to look up the records. I learn from that gentleman that no more than 750 copies of The United States were printed (in July, 1827), and of these, 502 were 'wasted' (in September, 1835). Mr Lawrence writes further: 'the work was sold and published by Simpkin, Marshall and Co. In fact, John Murray seems to have had little to do with it.' (From Sealsfield's letters one would gain a different impression.) 
Through the kind offices of Mr A. Ravizé, I have at last obtained a well-preserved copy of the missing book which turns out to be of singular importance in respect of a number of critical questions. My immediate object, however, is to establish the true title of the work and fix its relation to Die Vereinigten Staaten on the one hand and to The Americans on the other. The title reads: The | United States $\mid$ of $\mid$ North America | As they are ${ }^{1}$. London: | Published by W. Simpkin and R. Marshall | Stationers' Hall Court | MDCCCXXVIII. The volume is octavo and has 242 pages. The preface (vi pages) corresponds almost word for word to that of The Americans. It is dated London, June, 1827, while the preface to The Americans dates, or is, at least, alleged to date from March, 1828. The latter preface is evidently a doctored edition of the former. Sealsfield may have had nothing whatever to do with it. One might note the discrepancy of several years in dating the promulgation of the 'Monroe doctrine,' and the omission (in The Americans) of the author's apology for the 'many inaccuracies of his style.' To consider now the relation of The United States to the German original: it is, in fact, a mere free translation, or at most, in some parts, a rifacimento of the first volume of Die Vereinigten Staaten. Contrary to the generally accepted view, not one line of the second volume went to make up Murray's publication. The principal differences, apart from matters of phrasing, are these: 1 . Many of the long footnotes of the German edition are omitted, a few being taken up into the text. 2. The last chapter of The United States contains for the most part new matter, viz. a capital characterisation of America and its people. 3. A few errors in facts and names are corrected, e.g., 'Kongress von Panama' (Die Vereinigten Staaten, chap. 4), 'Congress of Mexico' (The United States, chap. 5). 4. Out of deference to English opinion, or from a sense of loyalty to the Germans, certain passages dealing with German and English character and manners are omitted, so from chapters 2 and 9. 5. The end of chapter 15 in Die Vereinigten Staaten is omitted, and for that of chapter 11 a different one is substituted. 6. The introductory chapter of The United States, which contains a review of the political, physical, and moral state of the Union of North America, concludes with a political observation added palpably ad captandam benevolentiam, for the special gratification of the British reader. Finally, the fifteen chapters of Die Vereinigten Staaten make eighteen

1 The contract between Charles Sealsfield and John Murray (see Faust, l.c., p. 184) contemplated a fuller title, and by this bibliographers have hitberto described the book in question. It is, however, only the half-title that runs: The United States of North America as they are in their political, religious and social bearings.

M. L. R. III. 
in the English version, owing to the addition of a final chapter as already mentioned, and the division of chapter 2 of the German work into 2 and 3 of the English, and of chapter 13 into 14 and 15.

In spite of the date 1828 on the title-page, the book was issued late in 1827, as appears both from the records of the publisher and the postscript to Sealsfield's letter to Cotta dated June 4, 1827 (Faust, l.c., p. 203). It would seem that John Murray 'sublet' the contract for The United States to Simpkin and Marshall.

\section{Tokeah, or The White Rose.}

The difficulty of finding Seadsfield's books through the usual channels was already realised in 1877 by that indefatigable compiler, Konstantin Wurzbach. To-day there is not a library anywhere, which is in possession of a complete set of Sealsfield's writings. One of the very rarest of his works is Tokeah. Joseph Sabin's Bibliotheca Americana, Vol. xv, mentions it as having been published at Philadelphia in 1829. The same year is given in the copyright notice on the reverse title-page of the second American edition. Yet Sealsfield scholars and bibliographers have invariably named 1828 as the year of publication. Failing, evidently, of access to a copy either of the first or of the second edition, they derived warrant for their date from the author's statement in the Introduction to Der Legitime und die Republikaner, Vol. I, p. xiii (cf. the 12mo edition): 'Einzig der Legitime und der Republikaner wurde zuerst in den Vereinigten Staaten zu Philadelphia bei Carey und Lea im Jahr 1828 in zwei Bänden unter dem Titel "Tokeah or The White Rose" herausgegeben, aber bloss der erste Teil in der deutschen bei Orell und Füssli in Zürich 1833 erschienenen Auflage unverändert gelassen, der zweite Teil hingegen gänzlich umgearbeitet.' Cf. also Sealsfield's letter to Brockhaus (Hamburger, Sealsfield-Postl, Vienna, 1879, p. 59). Tokeah is not to be found in the lists and reviews for 1828; also with the biographical data, albeit these are largely conjectural, 1829 would comport much better. I was therefore not surprised to find the first novel of Sealsfield mentioned among the 'new publications' of 1829 in the North American Review, Vol. xxviII (1829' p. 545: 'Novels and Tales. Tokeah or The White Rose, an American novel, Philadelphia, Carey, Lea and Carey, 2 vols., 12mo.' A good copy of this extremely rare book was recently acquired for the private library of Professor August Sauer. It is, for aught I know, the sole copy that can be located. Its ticle reads: Tokeah; | or, The White Rose.|(Follows 
a motto from Goethe.) | In two volumes | Philadelphia: | Carey, Lea and Carey,-Chestnut Street. | Sold in New York By G. \& C. Carvill, -in Boston By Munroe \& Francis. 1829. Volume I contains 212 pages, Volume II 208. The copyright was effected on January 14, 1829. The designation of Tokeah as an 'Indian' or 'American' novel is a bit of bibliographical supererogation, so far as the editio princeps is concerned. The second edition which is merely a popular reprint in cheap pamphlet form, but now equally rare, is entitled: Tokeah | or | The White Rose | An Indian Tale. | (The Motto from Goethe.) $\mid$ By $\mid$ C. Sealsfield. | Second Edition. | Philadelphia | Lea and Blanchard | 1845. I have likewise found a hitherto unregistered English edition in three well printed volumes: The | Indian Chief; | or, | Tokeah and The White Rose |...A Tale of the Indians and the Whites. |(The Motto from Goethe.) | Philadelphia: Carey, Lea and Carey|London: | A. K. Newman and Co. (The date has been erased. I have not yet been able to fix it.)

It would be well if these full descriptions should lead to the recovery of further copies of Tokeah: for the novel is indispensable to the comparative study of the American and European 'Indian story.' That it is still playing an influential part, especially in juvenile fiction, is proved by a number of quite recent reprints and 'Bearbeitungen,' even though most of them are based on the German version, Der Legitime und die Republikaner. For example, in English: Tokeah, or The White Rose, by Charles Sealsfield. London, G. Newnes, 1897. 2 vols. 8vo.: being Nos. 69-70 of The Penny Library of Famous Books. This edition is unfortunately out of print, and extremely difficult to obtain; there is a copy in the Bodleian, but none in the British Museum. The following titles, from my own collection, speak for the undiminished vitality of the book in Germany: 1. Tokeah. Für die reifere Jugend bearbeitet von H. Ludwig. Stuttgart, Thienemann. 4 vols. (No date.) 2. Tokeah oder die weisse Rose. Für die Jugend bearbeitet von P. Moritz. Stuttgart, Thienemann. 4 vols. (No date.) 3. Tokeah, etc., in Die besten Romane der Weltliteratur (Vols. X-XII). Wien, Leipzig, K. Prochaska, Teschen in Schlesien. (No date: 1896.) 4. Tokeah, etc., Frei für die Jugend bearbeitet von Gustav Höcker. Stuttgart, Berlin, Leipzig, Union Deutsche Verlagsanstalt. (No date.) 5. Tokeah, etc., Neu herausgegeben von Paul Heichen, in Charles Sealsfield's Wild-WestRomane. Gross-Lichterfelde, v. Pipersche Verlagsbuchhandlung. (No date: 1900.) 6. Tokeah, etc., in Klassische Romane der Weltliteratur. Ausgewählte Sammlung Prochaska. 2 vols. Wien, Leipzig, Teschen, K. Prochaska. (No date: 1904.) 


\section{Morton, ODER DIE GRosse Tour.}

Another extremely difficult book to find is the first edition of Morton. Faust, in his Johns Hopkins dissertation, gives the following title: '1835. Morton, oder die grosse Tour, vom Verfasser des Legitimen. Zürich, Orell, etc.' In Faust's Der Dichter beider Hemisphären, p. 105, the book is again called Morton, oder die grosse Tour. But in the subject-catalogues one searches in vain for 'Morton,' since, as a matter of fact, the name of the principal character did not form part of the title. Not many copies of the 1835 edition seem to be extant. One of these was located for me by the Berlin 'Auskunftsbureau' in the Royal Public Library at Dresden, whence Professor A. R. Hohlfeld (of Wisconsin) kindly sends me a transcription of the title: Lebensbilder | aus | beiden Hemisphären. | Vom Verfasser | des Legitimen, der Transatlantischen Reiseskizzen, | des Virey, etc. | Erster Theil | Zürich | bei Orell, Füssli und Comp. | 1835. (Vol. I, 183 pp., Vol. II, $206 \mathrm{pp}$.) In both volumes the sub-title, printed on a special page, reads merely: 'Die grosse Tour'.'

By his rather captious experimenting in the naming of his books Sealsfield managed at first to break up the continuity between Transatlantische Reiseskizzen (i.e. George Howard's, Esq. Brautfahrt) and its sequel, Ralph Doughby's, Esq. Brautfahrt, when he conjoined the latter story with Die grosse Tour as Lebensbilder aus beiden Hemisphären. To be sure, he did not intend to deny entirely the organic connection between Houard and Doughby, for in the editio princeps, Doughby is further described oder der Transatlantischen Reiseskizzen dritter Theil. But the serial title Lebensbilder aus beiden Hemisphären, erster Theil does not make a duly clear allowance for Howard as an integral part of the series. Apparently Sealsfield had conceived the ambitious design of a broad panorama of life on both sides of the Atlantic Ocean to be unrolled in a number of novels. Their collective name was to be Lebensbilder aus beiden Hemisphären, and so far as they dealt with American life solely, they were to be grouped together under the secondary collective title Transatlantische Reiseskizzen. But, as shown above, the diacritical value of the threefold title was lost in the confusion of the arrangement of 1835. The author abandoned the scheme in its more comprehensive form, and in the second edition, after separating out Morton, oder die grosse Tour as an independent novel,

I Since writing this note, I have obtained possession of a copy of the edition here accurately described. 
dropped the general superscription Lebensbilder aus beiden Hemisphären, and combined, quite properly, Howard with the succeeding Reiseskizzen in a set of six volumes under the new generic title Lebensbilder aus der westlichen Hemisphäre.

\section{CHRISTOPHORUS BÄRENHÄUTER.}

From Faust's list of Charles Sealsfield's works one gathers the false impression that the almost unknown story Christophorus Bärenhäuter and the well known George Howard's, Esq. Brautfahrt passed through two editions within two years. I am in a position to correct the dates and titles directly from the books themselves which Professor Faust has generously contributed to my loan-collection of Sealsfieldiana. The emendation would presumably have been made by Professor Faust himself in his Der Dichter beider Hemisphären, but for the regrettable omission of a bibliography from that monograph.

The two last items on page 52 of Faust's dissertation read:

'1833. Transatlantische Reiseskizzen und Christophorus Bärenhäuter, vom Verfasser des Legitimen. Zürich, 1833-37. 6 vols. Orell, Füssli u. Cie.

1834. George Howard's Brautfahrt und Christophorus Bärenhäuter. Bd. 1 und 2, Lebensbilder.'

In accordance with the facts these items should be entered as follows:

1834. Transatlantische Reiseskizzen und Christophorus Bärenhäuter. Vom Verfasser des Legitimen und der Republikaner. Zürich, bei Orell, Füssli und Comp. 2 vols. (Transatlantische Reiseskizzen is identical with the first edition of George Howard. A second edition of George Howard did not come out till 1843 ; Christophorus Bärenhäuter was never republished in book form.)

$1835 \mathrm{f}$. Lebensbilder aus beiden Hemisphären. (The component parts of the series, which, as is to be seen from the preceding note on Morton, contains also the continuations of Transatlantische Reiseskizzen, should be described volume for volume.)

OtTo HeLleR. 